\title{
ABCB1 2 Allele
}

National Cancer Institute

\section{Source}

National Cancer Institute. ABCB1 2 Allele. NCI Thesaurus. Code C45684.

Human ABCB1-T allele is a variant form of the human ATP-binding cassette, sub-family $B(M D R / T A P)$, member 1 (ABCB1) gene, located at 7q21.1, which encodes multidrug resistance protein 1. This allele exhibits a SNP (3435 C>T) in exon 26 that results in wobble. This alteration in DNA sequence decreases the in vivo catalytic activity of the protein encoded by the ABCB1-2 allele. Duodenal expression of multidrug resistance protein 1 is also significantly reduced in individuals that have a homozygous phenotype for this allele. 